\title{
AKRUAL
}

Jurnal Akuntansi

http://journal.unesa.ac.id/index.php/aj

\section{ANALYSIS OF GREEN ACCOUNTING TO SUPPORT CORPORATE SOCIAL RESPONSIBILITY \\ (CASE STUDY: SEMEN GRESIK HOSPITAL)}

\author{
Marisya Mahdia Khoirina \\ Faculty of Business and Economics, Universitas Internasional Semen Indonesia \\ marisya.khoirina@uisi.ac.id
}

\begin{abstract}
The Implementation of green accounting in hospital activities is the first step to solved environmental problems. Implementation of green accounting will work up the ability to minimize the environmental problem. The purpose of this accounting process is to improve the efficiency of environmental management by assessing environmental activities from a cost point of view (environmental cost). This research is a descriptive qualitative study using case studies method on Semen Gresik Hospital. This study aims to determine how to conduct environmental management and the application of the concept of green accounting. The research results revealed that Semen Gresik Hospital has not implemented the concept of green accounting yet. This can be seen in the identification of costs, there is no aspect of measurement and clear classification how a costs is categorized as environmental costs or not. The results also showed that the Semen Gresik Hospital had not made the environmental financial report.
\end{abstract}

Keywords: Environmental, Green Accounting, Hospital

\section{INTRODUCTION}

Nowadays, a lot of negative impact caused by the company's operations, a great negative impact that occur in the environment. Not a such few problems can arise due to neglect of environmental sustainability. Ministry of Environment (KLH) released the results of program performance rating of companies in environmental management (Proper) 2014 2015. As a result, there are 21 big companies that get listed in the black category (source: www.menlh.go.id). Black category is given to those who are doing business and / or activities, have been intentionally does any act or omission which causes pollution or environmental damage, violating the laws and regulations in force and / or imposing administrative sanctions.

Data from the Central Statistics Agency (BPS) in 2011 states the number of industries in Indonesia are 221.875 units. Of that amount, the company could potentially generate waste or contaminate the environment there are about 25.000 units. Meanwhile, there's only 1.812 units who's follow this Proper (about 8 percent). Based on data from the Ministry of Environment 2014-2015 Proper mentioned above, there are seven hospitals that get into the black list or conducting business and/or activities, have been 
intentionally does any act or omission which causes pollution or environmental damage, then, how with the remaining 92\%. How many of these 92\% were included Hospital industry and was entered into the black list.

From the hospital establishment requirements, one of requirements for waste treatment includes efforts Environmental Health (UKL), Environmental Monitoring Effort (UPL) or the Environmental Impact Assessment (AMDAL). However, many hospital industries are only considered to the terms of environmental management only to meet the requirements of the establishment of the Hospital. In fact, if there is no confirmation rules, the impact on the environment can be fatal. Hospital operating activities has the potential to cause environmental problems because waste produced is one of the hazardous waste. The types of medical waste including radioactive waste, infectious waste, pathology and anatomy, cytotoxic waste and chemical waste pharmaceuticals (Kepmenkes No.1204 / Menkes / SK / X / 2004). Based on the survey Environment Agency (2010) at 17 Hospital Large or small, the amount of waste generated reached 1,100 cubic meters per day. BPS data shows, the number of general hospitals in Indonesia amount 1,725 units and 513 units Special Hospital, as well as the 9655 units of health center. Then the potential number waste production is estimated at 769.478 cubic meters per day. If the waste management system is not done well, the potential to contaminate the hospital environment is quite large. The cost to overcome the impact is also great. This should be incentive for hospitals to improve environmental stewardship.

Many emerging ideas arise to help the realization of human welfare through these environmental issues. Environmental issues are having a rapid development that implicated for the changing needs of the stakeholders. The accounting study should be able to present the information in accordance with the needs of stakeholders. In connection with these demands, the accounting also has undergone rapid development so that in addition to conventional financial accounting, began to develop environmental accounting practices are also known as the concept of green accounting (Idris, 2012).

The concept of environmental accounting is actually starting to develop since the 1970s in Europe. Internal use Environmental Accounting produce environmental information to help make management decisions regarding price levels, control overhead, and capital budgeting. As for external interests, Environmental Accounting disclose environmental information to the public interest and other financial community. Information is presented in the Financial Statements of the Company (Financial 
Accounting Environment). Good use of internal and external use, the information provided is presented in the form of financial data.

According to Hamid (2002) in Agustia (2010), both at the micro or enterprise level, Environmental Accounting has important role in the company's efforts to implement environmental conservation activities. Environmental accounting gives a role in the three embodiments of accounting, the first financial accounting, environmental accounting role is to provide additional information through disclosure (disclosure) the fair or in the quantitative data on the components of the financial statements issued periodically and show the activities and results of operations of the company that includes the economic, social, and environmental. Second, Cost accounting, environmental accounting is used for a reasonable cost allocation and control of the activities of companies related to the company. Third, the Management Accounting, accounting environment play a role in management decision making.

Implementation of green accounting in hospital activities is the first step completed the solution of environmental problems. With the management of waste water in hospitals, for example, will increase operational costs associated. Implementation of green accounting would encourage the ability of hospitals to be able to record and post the costs related to the management of waste so as to minimize the environmental problems faced. The purpose of this accounting application is to improve the efficiency of environmental management by assessing environmental activities from a cost standpoint (environmental cost) and the benefits or effects (economic benefit).According Deegan (2003), the concept of green accounting can be applied also to non-governmental organizations and corporate stakeholders.

Based on the description above, this study discusses the application of green accounting in the hospital environment. The selection was based on the problem of contamination of hospital waste that has not become one of the main focus of management accountants to be able to support their CSR. Hospital as health organizations are expected to be responsible, to prevent or mitigate the impact of the bad things that might cause damage to the environment and community around the hospital. So the question of this study is:

How is the implementation of the Green Accounting practices as a CSR at the Semen Gresik Hospital? 


\section{RESEARCH METODHOLOGY}

This study uses qualitative research methods by using a descriptive approach. Qualitative research is a process of research based on the methodology to investigate a social phenomenon and the human problems (Bogdan \& Taylor, 1975). The using of qualitative methods in this study is intended to describe how the application of Green Accounting on Semen Gresik Hospital. This study uses multiple methods of data collection are as follows (Yulianto, 2008):

1. Observation. Observation is a data collection carried out directly into the field to observe the object to be investigated. The data is coming from Households Department and Department of Maintenance Facilities

2. Interview. Interview is the process of obtaining the data by face -to-face questions and answers between researchers and sources. The sources if this research is head of Households Department and Department of Maintenance Facilities

3. Use of Documents. Documentation is data collection techniques to collect and analyze written or unwritten documents, pictures or movies both personal and formal.

Processing the data in this study includes several stages, are as follows:

1. Data reduction. This process includes the perfection of data not only reduce the unnecessary and irrelevant data, but also additional data are still required.

2. Presentation of Data. Presentation of data is a set of structured information that provides the possibility of drawing conclusions and taking action (Huberman, 2009:17).

3. Interpretation of data. Interpretation of data is the process of understanding the meaning of a data set that has been presented, which not only look at what is written, but also to understand or interpret about what is implied in the data that has been presented.

4. Conclusion / verification. This conclusion is expressed in short sentences and easily to be understood, and is done by repeatedly to review the validity of this inference, particularly related with the relevance and consistency of the title, problems formulation, and the goals. 


\section{FINDING AND DISCUSSION}

\section{Environmental Management Activities}

In general, Decree of the Minister of Health No.1204 of 2004 as mentioned above serve as the main guideline in managing environment in the Semen Gresik Hospital. The activities of environmental managements, as stated in it, have been executed by Semen Gresik Hospital through several separated programs, are as follows:

1. Fire Prevention and Control Program are conducted by the Unit of Maintenance Facilities through security unit every month under the supervision of certificated outsourcing.

2. Healthy Work Environment Program conducted by Households Department and Department of Maintenance Facilities.

Healthy Work Environment, including infrastructure facilities. They have check regularly for the cleanliness of the building, rooms, and yard is free from danger and have minimal risk for the occurrence of cross-infection Activities in this program include: housekeeping regularly (garbage, cleaning floors, cleaning bathrooms and others), control the air regulation system (air conditioning, ventilation) and lighting, and P2K3 perform an audit to view the file inspection of Households Department and Department of Maintenance Facilities.

3. Hygiene, Food and Beverages Sanitation Program, these activities are carried out by the installation of Nutrition. The activities preserving kitchens' cleanliness; cutleries; preserving the dishes qualities; performing training for food cookers; and the healthy of the officer is always monitoring by the nutrition Installation.

4. Water recovery efforts are undertaken by Department of Maintenance Facilities. The activities are daily physical checks through tubs and tank to ensuring the water qualities.

5. Washing Recovery Program, this program is for linen laundry or activity commonly called a cleansing of soiled linen resulting from the use by each patient treatment rooms. Washing recovery programs are carried out by sub-unit laundry working under the supervision of Household Unit.

6. Management of waste, Waste management activities are a series of activities to minimize the possibility of environmental pollution caused by waste from the production of Infectious waste and Non-infectious waste. Hospital wastes are classified into 2 types: 
a. Infectious waste, is waste that the possibility of acquiring or can transmit the disease to the officer or employee. Examples disposable medical devices use, all former garbage worn by the contagious patient.

b. Non- infectious waste, the regular trash consisting of dry waste paper, plastics and others as well as the wet waste is household waste like kitchen waste and other

7. Controlling insects, rodents and other nuisance animals. All activities of insect controls and other nuisance animals are done by general helpers section.

8. Decontamination through disinfection and sterilization. Decontamination is an important first step in dealing with equipment, supplies, and other objects that are used to treat patients where the equipment has been contaminated. Disinfection is an attempt to eliminate the amount of pathogenic microorganisms that cause disease; while sterilization is an effort to eliminate all microorganisms both physically and chemically using SCCD.

9. Safety for Effects of Radiation. Safety for radiation effects is a safeguard effort for society from the impact of radiation, through the promotion and prevention of risk of radiation hazards by conducting monitoring activities, investigations on the source; ie: the environment and human media or devices which contain radiation.

10. Health Promotion Efforts of the Environmental Health Promotional efforts in this activity are the delivery of messages about hygiene and sanitation hospital to patients, families of patients, visitors, and employees. The promotional activities are carried out by public relations and marketing unit.

\section{Green Accounting in Semen Gresik Hospital}

Green accountings are process of identification; measurement; allocation of environmental costs; and integrating these costs into business decisions and communicate the results to stakeholder (Akhsan, 2008). The implementation of Green accounting in Semen Gresik hospital so far begins with the establishment of two departments; Households Department and Department of Maintenance Facilities. They are two special department that are in charge of environmental management activities. Focus for this activities will not optimal if it's not supported by good facilities and infrastructure. The entire infrastructures need to support environmental sanitation activities (such as waste management) require the operation costs. Transactions refer to these costs are accounted for using the cash basis for transaction revenue, expenditure, and financing. 
From the interview with the head of accounting, we can see that the implementation of environmental accounting by Semen Gresik Hospital so far has not been run which covers the process of identification, budgeting or allocation, the integration of environmental costs in decision-making, and communicate the result to the stakeholder. The overall expenses incurred in performing the management activities on the environment are identified by Semen Gresik Hospital as household cost. To show the consistency in keeping the hospital environment, these costs are budgeted each year. The detail of environment accounting application concepts by Semen Gresik Hospital has not been optimum yet. This example can be seen from the process of identification, budgeting, and communication of results is not optimal.

At the first step, Semen Gresik Hospital must be identifying their cost, based on their Environmental Management Activities. But, there is no clear method for measurement and classification of how a cost is categorized as environmental cost or not; this will have a direct impact on the budgeting process in the hospital's annual budget. This weak process of identifying environmental costs occurs because there are no specific guidelines which are being used as a

\section{CONCLUSION}

Based on the analysis of data and discussion, it can be concluded as follows:

1. Semen Gresik Hospital demonstrated their social responsibility (CSR) to the environment shape based on Health Ministry Regulations about hospital environmental health requirement. Various programs have been carried out by Semen Gresik hospital such as Fire Prevention and Control Program, Healthy Work Environment Program, Hygiene, Food and Beverages, Sanitation Program, Water recovery, means of identification and low intention to increase the accountability of the hospital environment.

Because there is no specific guidelines for green accounting, they hard to communicating the result of waste management activities, related costs, and environmental decision to the stakeholders, in this case: Semen Indonesia Foundation. Moreover, Semen Gresik Hospital indeed has not made any particular report which discusses about environmental management activities; how many environmental costs are required; number of environmental revenues; etc. The existing report is only a general report about Household Department and Facilities Maintenance Department's budget realization. These reports contain whole activities and costs incurred by those 
two units in performing their all routine activities, and give no special information about which activities or costs are related to environmental accounting matters.

The absence of environmental accounting report for environmental management activities (waste management) is resulting in failure to achieve the aims and objectives of the implementation of environmental accounting as already mentioned above. Semen Gresik Hospital should continue to make corrective actions and improvements to demonstrate their seriousness in implementing the concept of environmental accounting, as their CSR. Washing Recovery Program, Management of waste, Controlling insects, rodents and other nuisance animals, Decontamination through disinfection and sterilization, Safety for Effects of Radiation, and Health Promotion Efforts of the Environmental

2. The implementation of green accounting concept done by Semen Gresik Hospital still have points to improve, namely the process of identifying costs and communicating the results. This is are caused by no certain guidelines as the identification tool. While the weakness of communicating the results of the environmental management activities (waste management) can be seen from the absence of environmental accounting reports as a communication to the stakeholders of the company.

2.

Semen Gresik Hospital charged the environmental cost into their household expenses. They has not made a separate financial reporting to demonstrate environmental sanitation activities. Semen Gresik Hospital need a recommendation of environmental financial statement. Such as, how to classify the environmental costs into four categories: prevention costs, the cost of detection, internal failure costs, and external failure costs the environment. In addition, the report also presents the environmental benefits derived from environment management activities. 


\section{REFERENCES}

Agustia, Dian. 2010. Pelaporan Biaya Lingkungan Sebagai Alat Bantu Bagi Pengambilan Keputusan yang Berkaitan Dengan Pengelolaan Lingkungan. Jurnal Akuntansi: Akrual. Vol.1, No.2, April 2010: 80-100.

Arikunto. S. 2010. Prosedur Penelitian Suatu pendekatan praktik. Jakarta: PT. Rineka Cipta.

Belkaoui, A. R.., and Picur, R.D. 1991. Cultural determinism and the perception of accounting concepts. The International Journal of Accounting. 26:118-130.

Bogdan \& Taylor. 1975 dalam J. Moleong, Lexy. 1989. Metodologi Penelitian Kualitatif. Bandung: Remadja Karya.

Carroll, Archie B. 1991. The Pyramid of Corporate Social Responsibility: Toward The Moral Management of Organizational Stakeholders. Business Horizons.

Deegan, C. 2003. Environmental Management Accounting: An Introduction and Case Studies for Australian, Environment Australia, Environment protection authority: Victoria, Institute of Chartered Accountants Australia.

Drucker, Peter. F. 1984. Management Task. Responsibility. Practices Harper \& Row Publishing Company. New York.

Elkington, John. 1997. Cannibals with Forks. The Tripple Bottom Line of Twentieth Century Business. Harvard Business Review. Boston.

Ginsberg, J.M \& Paul N.B. 2004. Choosing the Right Green Marketing Strategy. MIT Sloan Management Review. Fall. Volume 4. No 01.

GRI. 2013. Sustainability Reporting Guidelines. www.globalreporting.org. diakses tanggal 16 Juni 2014

Idris. 2012. Akuntansi Lingkungan Sebagai Instrumen Pengungkapan Tanggung Jawab Perusahaan Terhadap Lingkungan di Era Green Market. Jurnal Economac, (online). Vol.2, No.2. http://manajemen.unnes.ac.id.

Irfan, Akhsan. 2008. Akuntansi Lingkungan dan Pengungkapannya. Jakarta: Salemba Empat.

Kementrian Kesehatan Republik Indonesia, "Data Rumah Sakit Online”, 2014. http://www.depkes.go.id (diakses tanggal 1 April 2016)

Lako, Andreas. 2014. Green Economy, Menghijaukan Ekonomi, Bisnis, dan Akuntansi. Jakarta: Erlangga.

Lindrianasari. 2007. Hubungan antara Kinerja Lingkungan dan Kualitas Pengungkapan Lingkungan dengan Kinerja Ekonomi Perusahaan di Indonesia. JAAI. Vol 11. No2.

Moleong, L.J. 2007.Metodologi Penelitian Kualitatif. Bandung: Penerbit PT Remaja Rosdakarya Offset.

Suartana, I Wayan. 2010. Akuntansi Lingkungan dan Tripple Bottom Line accounting: Paradigma Baru Akuntansi Bernilai Tambah. Jurnal Bumi Lestari. (online). Vol.10, No.1, Februari 2010: 105 - 112.

Subagyo, Pangestu. 2004. Statistik Terapan. Yogyakarta: BPFE.

Tanty, Heruna. 2003. Proses Pengolahan Limbah Rumah Sakit Harapan Kita Jakarta: Laporan Hasil Survei. INASEA 4 no 2. P. 85-93.

Uno, Kimio \& Peter Bartelmus. 2004. Environmental Accounting in Theory and Practice. Kluwer Publisher.

Wiedmann, T. \& Manfred, L. 2006. Third Annual International Sustainable Development Conference Sustainability-Creating the Culture. 15-16 November 2006, Perth, Scotland. 
Yakhou, Mehenna \& Vernon P. Dorweiler. 2004. Environmental Accounting:An

Essential Component of Business Strategy. Bus. Strat. Env., (online). Vol.13. 2004:

65-77.

www.menlh.go.id, (diakses 30 Mei 2016). 